\section{Jurnal Mitra Pendidikan (JMP Online)}

URL : http://e-jurnalmitrapendidikan.com
JMP Online

Vol. 4, No. 5, 269-280

(C) 2020 Kresna BIP. e-ISSN 2550-0481

p-ISSN 2614-7254

\title{
POTRET ETIKA PROFESI DALAM KASUS MUNDURNYA KHAIRIL ANWAR DAN KISRUH UJIAN NASIONAL
}

\author{
Johan Bhimo Sukoco \\ Universitas Diponegoro
}

INFORMASI ARTIKEL

Dikirim : 01 Juni 2020

Revisi pertama : 23 Juni 2020

Diterima : 24 Juni 2020

Tersedia online : 24 Juni 2020

Kata Kunci: Etika, Moral, Pejabat Publik

Email: johanbhimo@lecturer.undip.ac.id
ABSTRAK

Mundurnya Kepala Bagian Penelitian dan Pengembangan (Kabag Litbang) Kementerian Pendidikan dan Kebudayaan (Kemendikbud), Khairil Anwar Notodiputro menjadi salah satu kasus etika pejabat publik yang menarik perhatian. Surat pengunduran diri Kabag Litbang Kemndikbud tersebut disampaikan kepada Mendikbud, Mohammad Nuh pada 3 Mei 2013. Pengunduran diri Kabag Litbang Kemendikbud ini merupakan bentuk tanggung jawab moral pejabat publik. Pengunduran diri Kabag Litbang ini menimbulkan perdebatan. Dikaji dari segi etika, maka pejabat publik tersebut justru mundur dari jabatannya ketika amanah yang diembannya belum selesai. Namun, di sisi lain, mundurnya pejabat publik ini merupakan salah satu bentuk tanggung jawab moral pejabat publik yang gagal mengemban tugasnya. Artikel ini bermaksud mengkaji perihal sejauh mana bentuk etika dalammundurnya pejabat publik. 


\section{PENDAHULUAN \\ Latar Belakang}

Etika pejabat publik seringkali menjadi fenomena yang diperdebatkan oleh publik. Ryaas Rasyid (2007) menuliskan, bahwa setiap perilaku pejabat negara atau pejabat publik yang tidak mendukung serta menghambat berlangsungnya pelayanan publik, pemberdayaan dan pembangunan, maka hal ini sudah dapat dikategorikan sebagai pelanggaran etika pejabat publik. Lebih lanjut, M. Nasir Djamil dan TB Massa Djafar (2016), menuliskan bahwa etika pejabat negara dalam menjalankan pemerintahan yang bersih memiliki kedudukan yang sangat penting. Etika pejabat publik dijadikan rujukan dalam perilaku, serta sebagai pedoman moral dalam penyelenggaraan tertib pemerintahan. Oleh karena itu, melalui pejabat publik yang beretika baik akan mampu menciptakan pemerintahan yang tertib dan bersih pula.

Haryatmoko (2011), menuliskan bahwa etika publik ini perlu menjamin adanya integritas pejabat publik dalam penyelenggaraan pelayanan publik. Etika publik ini menuntut 3 (tiga) kompetensi pejabat publik, yaitu kompetensi teknis, kompetensi etika, dan kompetensi leadership / kepemimpinan. Beranjak dari hal ini, maka seyogyanya etika publik ini benar-benar menjadi pegangan pedoman bagi pengelolaan organisasi publik, agar pelayanan publik dapat terselenggara dengan baik dan etis.

Artikel ini mengkaji perihal mundurnya Kepala Bagian Penelitian dan Pengembangan (Kabag Litbang) Kementerian Pendidikan dan Kebudayaan (Kemendikbud), Khairil Anwar Notodiputro. Kasus kisruhnya Ujian Nasional dan dikuti mundurnya Kabag Litbang Kemendikbud menjadi salah satu kasus etika pejabat publik yang menarik perhatian. Surat pengunduran diri Kabag Litbang Kemendikbud tersebut disampaikan kepada Mendikbud, Mohammad Nuh pada tanggal 3 Mei 2013.

Dilihat dari kacamata moral, maka pengunduran diri Kabag Litbang Kemendikbud ini merupakan bentuk tanggung jawab moral pejabat publik. Namun demikian, pengunduran diri Kabag Litbang ini menimbulkan perdebatan, karena dikaji dari segi etika, maka pejabat publik tersebut justru mundur dari jabatannya ketika amanah yang diembannya belum selesai. Namun, di sisi lain, mundurnya pejabat publik ini merupakan salah satu bentuk tanggung jawab moral pejabat publik yang gagal mengemban tugasnya. Artikel ini bermaksud mengkaji perihal sejauh mana bentuk etika dalam mundurnya pejabat publik.

\section{Rumusan Masalah}

Berdasarkan latar belakang masalah, maka dapat diambil rumusan masalah, yaitu : bagaimana bentuk etika pejabat publik dalam kasus mundurnya Kepala Bagian Penelitian dan Pengembangan (Kabag Litbang) Kementerian Pendidikan dan Kebudayaan (Kemendikbud) Khairil Anwar Notodiputro?.

\section{Tujuan Penelitian}

Penelitian ini bertujuan untuk mengkaji dan menggambarkan sejauh mana bentuk etika dalam mundurnya pejabat publik, dalam kasus mundurnya Kepala 
Bagian Penelitian dan Pengembangan (Kabag Litbang) Kementerian Pendidikan dan Kebudayaan (Kemendikbud) Khairil Anwar Notodiputro.

\section{KAJIAN PUSTAKA}

Etika berasal dari bahasa Yunani, "Ethos", yang merupakan bentuk tunggal memiliki arti kebiasaan. Etika ini lekat dengan filsafat, nilai, dan moral, dimana etika bersifat abstrak dan berkenaan dengan persoalan terkait baik buruknya sesuatu (Haryo, dkk, 2015).

Etika dipahami sebagai refleksi atas segala yang baik dan buruk, salah atau benar, yang mana harus dilakukan atau bagaimana cara melakukannya dengan cara yang baik dan benar tersebut (Haryatmoko, 2011). Di sisi lain, Dennis F. Thompson (2002), menuliskan bahwa etika politik merupakan pengandaian bahwa pribadi-pribadi yang dinilai dapat memiliki tanggung jawab atas berbagai tindakan-tindakan yang mereka lakukan. Akan tetapi, struktur jabatan justru menilai sebaliknya, dimana seorang pejabat publik tersebut bertindak bersamasama dengan para pejabat lainnya dalam sebuah organisasi. Hal ini berarti bahwa masyarakat publik tidak dapat menerima tanggung jawab moral kepada siapapun atas sebuah konsekuensi dan kebijakan pemerintah.

Lebih lanjut, Franz Magnis Suseno (1993), menyebutkan bahwa etika politik merupakan bagian dari filsafat moral, yakni berkaitan dengan dimensi politis kehidupan manusia. Oleh karena itu, etika politik ini diartikan sebagai suatu standard nilai yang disarikan dari berbagai nilai-nilai kemanusiaan, dimana dijadikan sebagai kerangka acua teoritik dalam mempersoalkan serta menjelaskan berkaitan dengan legitimasi politik, dan budaya politik masyarakat. Beranjak dari sini, maka etika politik ini sejatinya mempertanyakan pertanggung jawaban serta kewajiban manusia sebagai mahluk bernama manusia, dan bukan hanya sebagai warga terhadap negara, melainkan hukum yang berlaku, dan lain sebagainya.

Beberapa peneliti pernah mengkaji terkait etika pejabat publik ini (M. Nasir Djamil dan TB Massa Djafar (2016), Rumsari Hadi Sumarto (2017), dan Mustika Prabaningrum Kusumawati (2019). Berikut ini hasil kajian masingmasing :

\section{Tabel 1. Penelitian Terdahulu}

\begin{tabular}{|l|l|c|l|l|}
\hline No & Nama Peneliti & Tahun & \multicolumn{1}{|c|}{ Judul Penelitian } & \multicolumn{1}{c|}{ Hasil Penelitian } \\
\hline (1) & \multicolumn{1}{|c|}{$(2)$} & $(3)$ & \multicolumn{1}{c|}{$(4)$} & \multicolumn{1}{c|}{ (5) } \\
\hline 1. & $\begin{array}{l}\text { M. Nasir } \\
\text { Djamil dan TB } \\
\text { Massa Djafar }\end{array}$ & 2016 & $\begin{array}{l}\text { Etika Publik } \\
\text { Pejabat Negara } \\
\text { dalam } \\
\text { Penyelenggaraan } \\
\text { Pemerintahan } \\
\text { yang Bersih }\end{array}$ & $\begin{array}{l}\text { Pelanggaran etika pejabat publik } \\
\text { digambarkan berupa perilaku } \\
\text { tidak jujur, manipulasi data, dan } \\
\text { tidak adanya transparansi agar } \\
\text { proyek disetujui. Pelanggaran } \\
\text { etika pejabat publik ini diikuti } \\
\text { dengan pelanggaran hukum, yang } \\
\text { memiliki implikasi pada } \\
\text { menurunnya kepercayaan publik } \\
\text { dalam upaya menciptakan } \\
\text { pemerintahan yang bersih, } \\
\text { khususnya bagi pejabat publik } \\
\text { yang brasal dari partai politik. }\end{array}$ \\
& & & &
\end{tabular}


Lanjutan Tabel 1. Penelitian Terdahulu

\begin{tabular}{|c|c|c|c|c|}
\hline No & Nama Peneliti & Tahun & Judul Penelitian & Hasil Penelitian \\
\hline (1) & (2) & (3) & (4) & (5) \\
\hline 2. & $\begin{array}{l}\text { Rumsari Hadi } \\
\text { Sumarto }\end{array}$ & 2017 & $\begin{array}{l}\text { Etika Publik Bagi } \\
\text { Kepemimpinan } \\
\text { Pemerintah } \\
\text { Daerah }\end{array}$ & $\begin{array}{l}\text { Etika pejabat publik idealnya } \\
\text { menjadi pegangan bagi pemimpin } \\
\text { dalam mengelola organisasi } \\
\text { publik. Hal ini penting mengingat } \\
\text { agar pelayanan publik dapat } \\
\text { terealisasi dengan baik dan } \\
\text { mmenuhi prinsip-prisip yang etis. }\end{array}$ \\
\hline 3. & $\begin{array}{l}\text { Mustika } \\
\text { Prabaningrum } \\
\text { Kusumawati }\end{array}$ & 2019 & $\begin{array}{l}\text { Harmonisasi } \\
\text { Antara Etika } \\
\text { Publik dan } \\
\text { Kebijakan Publik }\end{array}$ & $\begin{array}{l}\text { Hasil riset ini menunjukkan } \\
\text { bahwa ketika seorang pejabat } \\
\text { publik tidak memiliki kemampuan } \\
\text { dalam memisahkan secara tegas } \\
\text { antara domain pribadi dengan } \\
\text { publik, maka akan memiliki } \\
\text { korelasi dengan pelayanan publik. } \\
\text { Kondisi ini tidak hanya dipicu } \\
\text { oleh pejabat publik yang tidak } \\
\text { dapat menghayati arti pentingnya } \\
\text { nilai etika pejabat publik, } \\
\text { melainkan juga diperparah dengan } \\
\text { pejabat publik yang tidak } \\
\text { mengetahui apa itu sebenarnya } \\
\text { kaidah etika pejabat publik. }\end{array}$ \\
\hline
\end{tabular}

Sumber : M. Nasir Djamil dan TB Massa Djafar (2016), Rumsari Hadi Sumarto (2017), dan Mustika Prabaningrum Kusumawati (2019).

Beberapa penelitian ini bermanfaat dalam mengkaji etika pejabat publik. Namun demikian, belum banyak peneliti yang secara fokus membahas mengenai etika pejabat publik yang dikaitkan dengan fenomena mundurnya pejabat publik dari jabatannya. Penelitian ini akan lebih fokus mengkaji permasalahan tersebut.

\section{METODE PENELITIAN}

Penelitian ini merupakan penelitian deskriptif kualitatif. Penelitian ini menggambarkan perihal mundurnya Kepala Bagian Penelitian dan Pengembangan (Kabag Litbang) Kementerian Pendidikan dan Kebudayaan (Kemendikbud), Khairil Anwar Notodiputro. Kondisi kejadian berfokus pada tahun 2013 lalu, dengan subjek penelitian orang. Lokus penelitian ini berfokus di Kementerian Pendidikan dan Kebudayaan (Kemendikbud). Teknik pengumpulan data menggunakan studi dokumen, yaitu dengan mengumpulkan beberapa literatur terkait fenomena penelitian ini. Teknik analisis data menggunakan model analisis interaktif, baik antar komponen pokok (reduksi data, sajian data, penarikan kesimpulan serta verifikasinya), maupun dengan proses pengumpulan data yang berbentuk siklus, seperti yang dikemukakan Miles and Hubberman (H.B. Sutopo, 2002 : 91-93). 


\section{ISI PEMIKIRAN DAN PEMBAHASAN}

Kepala Bagian Penelitian dan Pengembangan Kementerian Pendidikan dan Kebudayaan, Khairil Anwar Notodiputro mengundurkan diri terkait kisruhnya pelaksanaan Ujian Nasional (UN). Surat pengunduran diri tersebut telah disampaikan kepada Mendikbud, Mohammad Nuh pada 3 Mei 2013. Pengunduran diri Kabag Litbang dilakukan sebelum investigasi yang dilakukan Inspektorat Jenderal Kemendikbud selesai. Selain Kabag Litbang, juga terdapat pejabat Eselon II lainnya yang akan dijatuhi sanksi sesuai rekomendasi dari inspektorat. Namun demikian, sanksi itu baru akan diberikan setelah proses evaluasi Ujian Nasional secara keseluruhan selesai.

Inu Kencana Syafiie, dkk (1999 : 216), mengutip pernyataan Leys, yang menyatakan bahwa seorang administrator akan dianggap etis apabila dia mampu menguji dan mempertanyakan batas yang digunakan dalam pembuatan keputusan, dan tidak mendasarkan keputusannya semata-mata pada kebiasaan dan tradisi yang sudah ada.

Pengunduran diri pejabat publik ini merupakan bentuk moralitas pejabat publik. Hal ini bagai uang logam yang mempunyai dua sisi. Sisi pertama, nampak bahwa pejabat publik memiliki moral yang baik karena bersedia mundur dari jabatan yang menjadi kesalahannya, sedangkan sisi kedua, nampak bahwa pejabat publik memiliki moral yang buruk karena turun jabatan dan memilih mengundurkan diri sebelum masa jabatannya selesai akibat kesalahannya.

Pendidikan pada dasarnya membentuk budaya yang baik, sehingga perlu pengawalan Kementerian Pendidikan dan Budaya dengan baik. Menurut H.A.R. Tilaar (2003:171), pendidikan bukan hanya sekadar pengawal (guardian) masa lalu dalam fungsinya sebagai preservator budaya, juga bukan hanya menyiapkan peserta didik untuk masa depannya, pendidikan itu terutama bertanggung jawab terhadap generasi masa kini.

Menteri Pendidikan dan Kebudayaan, Muhammad Nuh, menyampaikan secara resmi pengunduran diri Kabag Litbang Kemendikbud. Dimana dalam laporan lisannya, Muhammad Nuh menyampaikan bahwa ia mendapatkan arahan dari Presiden agar menyampaikan hasil investigasi kepada publik. Pengunduran diri tersebut memang wajib dilaporkan kepada presiden karena Kabag Litbang Kemendikbud menduduki posisi Eselon I. Hal ini dikarenakan, untuk eselon I, yang mengangkat dan memberhentikan adalah presiden.

Pengunduran diri Kabag Litbang Khairil Anwar tersebut sama dengan sanksi moral yang bisa diberikan. Lebih lanjut, Golembiewski (Inu Kencana Syafiie, dkk, 1999 : 216), menyatakan bahwa batas etika tersebut mungkin berubah dari waktu ke waktu, dan karena itu para administrator harus mampu memahami pertimbangan ketentuan batas-batas tersebut dan bertindak sesuai dengan batas perilaku tersebut.

Beberapa regulasi pemerintah terkait etika pejabat publik sebenarnya sudah tertuang jelas dalam beberapa peraturan. Peraturan Pemerintah Nomor 42 Tahun 2004 tentang Pembinaan Jiwa Korps dan Kode Etik Pegawai Negeri Sipil, Peraturan Menteri Pendayagunaan Aparatur Negara dan Reformasi Birokrasi Nomor 21 Tahun 2012 Tentang Kode Etik Pegawai Kementerian Pendayagunaan Aparatur Negara dan Reformasi Birokrasi, dan Undang-Undang Republik 
Indonesia Nomor 5 Tahun 2014 Tentang Aparatur Sipil Negara, sudah mengatur mengenai etika ini. Berikut ini dapat dilihat dalam tabel berikut ini :

Tabel 2. Regulasi Etika Publik

\begin{tabular}{|c|c|c|}
\hline No. & Regulasi & Isi Regulasi \\
\hline (1) & (2) & (3) \\
\hline 1. & \begin{tabular}{lcrr} 
Peraturan & \multicolumn{2}{r}{ Pemerintah } \\
Nomor & 42 Tahun & 2004 \\
tentang & Pembinaan & Jiwa \\
Korps dan & Kode & Etik \\
Pegawai Negeri Sipil. &
\end{tabular} & $\begin{array}{l}\text { Pasal 1, dituliskan bahwa : "Kode Etik } \\
\text { Pegawai Negeri Sipil adalah pedoman } \\
\text { sikap, tingkah laku, dan perbuatan Pegawai } \\
\text { Negeri Sipil di dalam melaksanakan } \\
\text { tugasnya dan pergaulan hidup sehari-hari." } \\
\text { Pasal 7, disebutkan : "Dalam pelaksanaan } \\
\text { tugas kedinasan dan kehidupan sehari-hari } \\
\text { setiap Pegawai Negeri Sipil wajib bersikap } \\
\text { dan berpedoman pada etika dalam } \\
\text { bernegara, dalam penyelenggaraan } \\
\text { Pemerintahan, dalam berorganisasi, dalam } \\
\text { bermasyarakat, serta terhadap diri sendiri } \\
\text { dan sesama Pegawai Negeri Sipil yang } \\
\text { diatur dalam Peraturan Pemerintah ini." }\end{array}$ \\
\hline 2. & \begin{tabular}{lr} 
Peraturan & \multicolumn{2}{c}{ Menteri } \\
Pendayagunaan & \multicolumn{2}{c}{ Aparatur } \\
Negara dan & Reformasi \\
Birokrasi Nomor & 21 Tahun \\
2012 Tentang & Kode Etik \\
Pegawai & Kementerian \\
Pendayagunaan & Aparatur \\
Negara dan & Reformasi \\
Birokrasi. &
\end{tabular} & $\begin{array}{l}\text { Pasal 1, dituliskan bahwa : "Kode Etik } \\
\text { Pegawai Kementerian Pendayagunaan } \\
\text { Aparatur Negara dan Reformasi Birokrasi } \\
\text { yang selanjutnya disebut kode etik, adalah } \\
\text { pedoman sikap, perilaku, perbuatan, tulisan } \\
\text { dan ucapan pegawai dalam melaksanakan } \\
\text { tugas pokok dan fungsi serta kegiatan } \\
\text { sehari-hari." } \\
\text { Pasal 3, tertulis : "Kode Etik bertujuan } \\
\text { menjaga martabat, kehormatan, citra dan } \\
\text { kredibilitas Kementerian Pendayagunaan } \\
\text { Aparatur Negara dan Reformasi Birokrasi } \\
\text { serta menciptakan keharmonisan sesama } \\
\text { pegawai, dalam rangka mencapai dan } \\
\text { mewujudkan visi dan misi organisasi." } \\
\text { Pasal 4, disebutkan bahwa : "Ruang } \\
\text { Lingkup Kode Etik terdiri dari: a. Sikap; b. } \\
\text { Perilaku; c. Perbuatan; d. Tulisan; dan e. } \\
\text { Ucapan pegawai." }\end{array}$ \\
\hline
\end{tabular}


Lanjutan Tabel 2. Regulasi Etika Publik

\begin{tabular}{|c|c|c|}
\hline No. & Regulasi & Isi Regulasi \\
\hline (1) & (2) & (3) \\
\hline 3. & 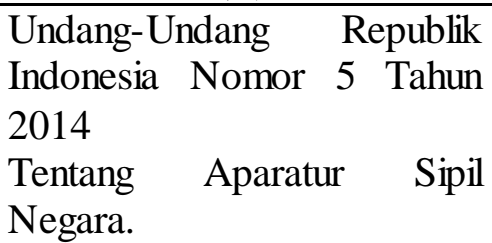 & $\begin{array}{l}\text { Pasal 5, tertulis : "Kode etik dan kode } \\
\text { perilaku sebagaimana dimaksud dalam } \\
\text { Pasal } 3 \text { huruf b bertujuan untuk menjaga } \\
\text { martabat dan kehormatan ASN." }\end{array}$ \\
\hline
\end{tabular}

Sumber : Peraturan Pemerintah Nomor 42 Tahun 2004, Peraturan Menteri

Pendayagunaan Aparatur Negara dan Reformasi Birokrasi Nomor 21 Tahun 2012, dan Undang-Undang Republik Indonesia Nomor 5 Tahun 2014 Tentang Aparatur Sipil Negara.

Di dalam kasus Khairil Anwar ini, jika dalam perkembangannya terdapat pihak lain yang bersalah seperti eselon II atau pejabat lainnya, tetap akan diberikan sanksi sesuai rekomendasi dari inspektorat. Namun demikian, kelanjutkan pemberian sanksi tersebut belum akan direalisasi, dikarenakan proses investigasi masih berlanjut.

Pada dasarnya sumber permasalahan dalam kasus ini adalah terkait dengan semrawutnya Ujian Nasional (UN) yang diselenggarakan oleh Kementerian Pendidikan dan Kebudayaan. Hal ini tentu saja mendapat sorotan tajam masyarakat. Zainal Abidin Ahmad (1970:15), seorang pendidik besar Perancis, yang terkenal dengan bukunya berjudul "Aqeuitient Superiorite de Anglo Saxons" (Superiornya bangsa Inggris), dalam salah satu bab terpentingnya menyatakan, apabila kita hendak menyimpulkan jawaban tentang persoalan masyarakat dalam suatu patah kata, maka kata itu ialah Pendidikan.

Pejabat publik mengundurkan diri memang menjadi fenomena yang menarik. Fenomena ini cukup baru, karena sebelumnya tidak banyak pejabat publik yang berani mengundurkan diri dari status formalnya. Pilihan sikap untuk mengundurkan diri ini tentu saja dapat memancing perdebatan publik. Sikap pro dan kontra yang berkembang di tengah masyarakat tentunya memiliki nilai benar dan salah. Hal ini memang bergantung dari aspek mana melihat kasus tersebut.

Terkait dengan permasalahan pengunduran diri pejabat publik ini, permasalahan utamanya ialah ketidaksanggupan dalam menjalankan amanah di bidang pendidikan. Kemsewrawutan Ujian Nasional menjadi sumber permasalahannya. Menurut H.A.R. Tilaar (2003:171), dalam menghadapi peranan pendidikan, perlu diingat bahwa pendidikan itu merupakan suatu proses yang berkesinambungan. Dalam mempersiapkan masyarakat industri modern masa depan, bersamaan dengan itu harus mengatasi masalah pendidikan masa kini yang tentunya akan berpengaruh terhadap wajah dunia pendidikan masa depan.

Permasalahan pendidikan ini sebenarnya bukan hanya masalah kesemrawutan Ujian Nasional saja. Disisi lain, banyak permasalahan pendidikan yang belum dapat diatasi oleh Kementerian Pendidikan dan Kebudayaan. Menurut Eko Prasetyo (2006:21), hingga 2002 tercatat sebanyak 17.079.220 dari 220 juta lebih penduduk Indonesia atau $7,763 \%$ yang tidak bisa baca tulis. Mereka dinyatakan buta aksara. Sedangkan untuk anak-anak pra sekolah berusia 4-6 tahun 
yang belum tertampung pada lembaga pendidikan sebanyak 11.298 .070 orang. Mereka yang mengalami putus Sekolah Dasar per tahunnya ada sekitar 3 juta orang.

Masalah pendidikan telah lama disadari. Namun, dengan dalih keterbatasan dana serta berbagai undang-undang dan peraturan yang berlaku, selalu dijadikan dalih untuk menunda-nunda pemecahan masalah tersebut. Sulitnya membangun sarana pendidikan karena hambatan-hambatan tertentu perlu segera dibenahi. Diperlukan berbagai terobosan dalam pendekatannya, atau memerlukan penanganan khusus (spesial effort), (H.A.R. Tilaar (2003:111).

Beberapa media massa turut memberitakan pengunduran Kabag Litbang Kemendikbud Khairil Anwar ini. Berikut ini beberapa media massa yang memuat pemberitaan tersebut :

Tabel 3. Peliputan Media Massa

\begin{tabular}{|c|c|c|c|c|}
\hline No. & Nama Media & $\begin{array}{c}\text { Tanggal } \\
\text { Publikasi }\end{array}$ & $\begin{array}{c}\text { Judul } \\
\text { Publikasi }\end{array}$ & Link Publikasi \\
\hline (1) & (2) & (3) & (4) & (5) \\
\hline 1. & Republika.co.id & $\begin{array}{l}14 \text { Mei } \\
2013\end{array}$ & $\begin{array}{l}\text { Khairil } \\
\text { Mundur } \\
\text { Terkait Ujian } \\
\text { Nasional }\end{array}$ & $\begin{array}{l}\text { https://www.republika.co } \\
\text { id/berita/koran/news- } \\
\text { update/13/05/13/mmqr46 } \\
\text {-khairil-mundur-terkait- } \\
\text { ujian-nasional } \\
\end{array}$ \\
\hline 2. & Liputan6.com & $\begin{array}{c}13 \text { Mei } \\
2013\end{array}$ & $\begin{array}{c}\text { Kisruh UN, } \\
\text { Kemendikbud } \\
\text { Pecat Kepala } \\
\text { Litbang Khairil } \\
\text { Anwar }\end{array}$ & $\begin{array}{l}\text { https://www.liputan6.co } \\
\text { m/news/read/585014/kisr } \\
\text { uh-un-kemendikbud- } \\
\text { pecat-kepala-litbang- } \\
\text { khairil-anwar }\end{array}$ \\
\hline 3. & Tempo.co & $\begin{array}{l}27 \text { Juni } \\
2013\end{array}$ & $\begin{array}{c}\text { Bilang } \\
\text { Ngantor, } \\
\text { Kabalitbang } \\
\text { Kemendikbud } \\
\text { 'Ngantor' }\end{array}$ & $\begin{array}{l}\text { https://nasional.tempo.co } \\
\text { /read/491689/bilang- } \\
\text { mundur-kabalitbang- } \\
\text { kemendikbud-ngantor }\end{array}$ \\
\hline 4. & Viva.co.id & $\begin{array}{c}13 \mathrm{Mei} \\
2013\end{array}$ & $\begin{array}{l}\text { UN Kisruh, } \\
\text { Kabag Litbang } \\
\text { Kemendikbud } \\
\text { Mundur }\end{array}$ & $\begin{array}{l}\frac{\text { https://www.viva.co.id/be }}{\text { rita/nasional/412551-un- }} \\
\text { kisruh-kabag-litbang- } \\
\text { kemendikbud-mundur }\end{array}$ \\
\hline
\end{tabular}

Sumber : Republika.co.id (2013), Liputan6.com (2013), Tempo.co (2013),

Viva.co.id (2013).

Pengunduran diri pejabat publik seperti yang dilakukan oleh Kabag Litbang Kemendikbud Khairil Anwar ini memang kontroversial. Pengunduran pejabat publik memang menjadi masalah yang marak mendapat sorotan publik. Pengunduran diri pejabat publik seolah mendapatkan payung hukum. Simak saja PP No. 9 Tahun 2004 yang mengatur tentang kampanye oleh pejabat Negara. Pejabat Negara yang melakukan kampanye politik disarankan mengambil cuti atau nonaktif dari jabatannya. 
Menurut Soedjatmoko (Faisal Kasryno dan Joseph F. Stepanek, 1985:78), pendekatan dalam bidang pendidikan menuntut adanya titik berat pada kemampuan yang fungsional. Hal ini berarti bahwa sejauh pendidikan formal tidak dapat memenuhinya, harus dicapai lewat berbagai bentuk pendidikan non-formal. Jadi, dalam hal ini perlu partisipasi antara pendidikan formal dengan pendidikan non-formal. Pihak-pihak masyarakat civil perlu berpartisipasi pula dalam mengatasi problem pendidikan ini. Dapat dikatakan bahwa masalah pendikan memerlukan kerjasama antara pemerintah dengan masyarakat dalam penganannya. Dari fenomena pengunduran diri Kabag Litbang Kemendikbud Khairil Anwar di atas, muncul pertanyaan mendasar yaitu mengapa para pejabat publik harus mengundurkan diri dari jabatan yang dipercayakan oleh publik. Selain itu, muncul juga pertanyaan bahwa apakah sebenarnya pemerintahan hanya dianggap sebagai permainan yang tanpa menghiraukan implikasinya kepada publik. Di sisi lain juga muncul pertanyaan, bagaimana pertanggungjawaban para pejabat publik ini kepada publik. Menurut masyarakat awam, pengunduran diri pejabat publik ini adalah tindakan yang beretika. Padahal, sejatinya hal ini tidak serupa dengan definisi etika menurut teori.

Inu Kencana Syafiie (1999 : 215), menuliskan etika artinya sama dengan kata Indonesia "kesusilaan", yang berasal dari bahasa sanksekerta, "susila". Apabila dipenggal, "su" artinya baik, sedangkan "sila" artinya norma kehidupan. Jadi, susila atau etika berarti menyangkut kelakuan yang mengikuti norma-norma kehidupan yang baik. Sementara itu, etika sebenarnya berasal dari bahasa Yunani,"ethos", yang berarti watak atau adat. John P.Noman (1948), menyebut bahwa "Ethics is the science of the morality of human act" (artinya, etika adalah ilmu tentang budi pekerti dan cara tindak manusia).

Pada awalnya, masyarakat awam akan takjub dengan adanya pengunduran diri pejabat publik ini. Muncul rasa simpati yang diberikan kepada pejabat publik yang mengundurkan diri tersebut. Bahkan publik kadangkala dengan cepat memberikan sanjungan sebagai pahlawan kebenaran yang berani menunjukkan sikapnya. Pejabat publik yang mengundurkan diri ini dinilai sebagai sosok yang memiliki komitmen terhadap perjuangan reformasi. Namun demikian, jika masyarakat mengikuti sepak terjang apa yang berikutnya dilakukan oleh mantan pejabat publik tersebut, maka masyarakat menjadi menyesal Sikap mengundurkan diri tersebut ternyata bermuatan politik.

Pengunduran diri Khairil Anwar sebagai Kabag Litbang Kemendikbud ini tentu saja menjadi preseden buruk dalam wacana sistem pemerintahan. Di tengah masyarakat yang masih kental kultur paternalistiknya, sikap mengundurkan diri akan menjadi bagian latah dari masyarakat. Masyarakat tentu saja akan meniru sikap pejabat yang mengundurkan diri tersebut, yang tentunya dengan kepentingan yang hampir sama.

Hal yang ditakutkan adalah bahwa pejabat publik yang mengundurkan diri tersebut, seperti yang dilakukan Khairil Anwar ini, maka dikhawatirkan akan membuat kelatahan di lingkup jabatan lainnya. Pejabat publik di level manapun baik di tingkat pusat maupun daerah dikawatirkan akan memiliki kebiasaan baru tersebut. Hal ini tentu berdampak negatif terhadap kinerja mereka. Konsentrasi kerja mereka sudah kurang terfokus. Dari kondisi tersebut, tergambar bahwa 
pekerjaan publik seolah menjadi permainan. Pejabat publik dengan begitu mudahnya melepaskan jabatan yang sangat penting bagi stabilitas rakyat, secara ekonomi dan politik. Jika kondisi tersebut tidak diantisipasi dengan kekuatan payung hukum yang jelas, maka preseden buruk itupun akan berlanjut. Setiap ada peluang yang bisa diraih oleh pejabat publik, maka jabatan lama akan ditinggalkan begitu saja. Dengan begitu, pemerintahan sebenarnya sudah tidak sehat lagi. Pemerintahan pun bisa mengalami stagnasi.

Hebert A. Simon (1947), dalam bukunya yang berjudul "Administrative Behaviour" (dalam Yeremias T. Keban, 2004 : 145), yang mengingatkan bahwa para administrator ternyata dalam membuat keputusan cenderung didasarkan pada pertimbangan-pertimbangan di luar rasionalitas atau di luar pertimbangan ekonomi dan efisiensi. Terkait hal ini, para administrator nampaknya sangat dipengaruhi oleh faktor sosial dan psikologi, sehingga berdampak pada keputusan yang mereka buat.

Yeremias T. Keban (2004:146), lebih lanjut, menyatakan bahwa etika dapat menjadi suatu faktor yang mesukseskan tetapi juga sebaliknya menjadi pemicu dalam menggagalkan tujuan kebijakan, struktur organisasi, serta manajemen publik. Jika moralitas para penyusun kebijakan publik rendah, makakualitas kebijakan kualitas kebijakan yang dihasilkan pun sangat rendah. Begitu pula jika struktur organisasi publik yang disusun berdasarkan kepentingankepentingan tertentu yang berbeda dengan kepentingan publik, maka struktur organisasi publik tersebut tidak akan efektif dalam menjalankan tugas dan fungsinya.

Sudah seharusnya pendidikan menjadi garda terdepan dalam focus yang diperhatikan pemerintah. Permasalahan pengunduran diri Khairil Anwar sebagai Kalitbang Kemendikbud ini dapat menjadi preseden buruk dalam dunia pendidikan. Padahal, menurut Siti Meichati (1980:6), pendidikan adalah suatu hasil peradaban sebuah bangsa yang dikembangkan atas dasar suatu pandangan hidup bangsa itu sendiri, sebagai suatu pengalaman yang memberikan pengertian, pandangan, dan penyesuaian bagi seseorang yang menyebabkan mereka berkembang.

Pendidikan telah diamanahkan dalam UUD 1945 Pasal 31. Pada Pasal 31 ayat 1, dikatakan bahwa tiap-tiap warga negara berhak mendapatkan pengajaran. Pasal 31 ayat 2, berbunyi pemerintah mengusahakan dan menyelenggarakan satu sistem pengajaran nasional, yang diatur undang-undang. Amanah ini diturunkan ke berbagai kebijakan, salah satunya Undang-undang Nomor 20 Tahun 2003 tentang Sistem Pendidikan Nasional yang mengamanatkan pemerintah pusat dan daerah wajib memberikan layanan kemudahan, serta menjamin pendidikan yang layak.

\section{KESIMPULAN DAN SARAN \\ Kesimpulan}

Sebagai penutup artikel ini dapat disimpulkan bahwa mundurnya Kepala Bagian Penelitian dan Pengembangan (Kabag Litbang) Kementerian Pendidikan dan Kebudayaan (Kemendikbud), Khairil Anwar Notodiputro ini merupakan bentuk potret etika di Indonesia. Permasalahan ini, apabila dilihat dari kacamata moral, maka pengunduran diri ini merupakan bentuk tanggung jawab moral 
pejabat publik secara beretika. Namun, hal ini menimbulkan perdebatan, karena dikaji dari segi etika, maka pejabat publik tersebut mundur dari jabatannya ketika amanah yang diembannya belum selesai. Meskipun di sisi lain mundurnya pejabat publik ini merupakan salah satu bentuk tanggung jawab moral pejabat publik yang gagal mengemban tugasnya. Jadi, mundurnya pejabat publik ini merupakan bentuk potret etika.

\section{Saran}

Penelitian ini merekomendasikan perlunya kajian lebih lanjut terkait mundurnya pejabat publik dari jabatannya. Penilaian masyarakat dalam mengkaji kasus mundurnya Kepala Bagian Penelitian dan Pengembangan (Kabag Litbang) Kementerian Pendidikan dan Kebudayaan (Kemendikbud), Khairil Anwar Notodiputro, ini, idealnya menggunakan dua "kacamata" yang berbeda. Masyarakat perlu menilai dari dua sudut pandang, yakni dari belum diselesaikannya amanah tanggung jawab dalam jabatan, serta dari sudut pandang sebagai bentuk pertanggung jawaban moral pejabat publik yang gagal mengemban tugasnya.

\section{DAFTAR PUSTAKA}

Dennis F. Thompson. 2002. Etika Pejabat Negara (terj. Benyamin Molan). Jakarta: Yayasan Obor Indonesia.

Eko Prasetyo. 2006. Orang Miskin Dilarang Sekolah. Yogyakarta: Resist Book.

Faisal Kasryno dan Joseph F. Stepanek. 1985. Dinamika Pembangunan Desa. Jakarta: Yayasan Obor Indonesia dan PT Gramedia.

Franz Magnis Suseno. 1993. Etika Dasar (cet. 6). Jakarta: Kanisius.

Haryatmoko. 2011. Etika Publik, untuk Integritas Pejabat Publik dan Politisi. Jakarta: Gramedia Pustaka Utama.

Haryo Kunto Wibisono, Linda Novi Trianita, Sri Widagdo. 2015. Dimension of Pancasila Ethics in Bureaucracy: Discourse Of Governance. Jurnal Fokus. Volume 12 Nomor 7, Tahun 2015.

H.A.R. Tilaar. 2003. Manajemen Pendidikan Indonesia. Bandung: PT Remaja Rosdakarya.

H.B. Sutopo. 2002. Metode Penelitian Kualitatif - Dasar Teori dan Terapannya dalam Penelitian. Surakarta : Sebelas Maret University Press.

Inu Kencana Syafiie, Djamaludin Tandjung, dan Supardan Modeong. 1999. Ilmu Administrasi Publik. Jakarta : Rineka Cipta.

M. Nasir Djamil dan TB Massa Djafar. 2016. Etika Publik Pejabat Negara dalam Penyelenggaraan Pemerintahan yang Bersih. Jurnal Kajian Politik Dan Masalah Pembangunan. Volume 12 Nomor 01, Tahun 2016.

Mustika Prabaningrum Kusumawati. 2019. Harmonisasi Antara Etika Publik Dan Kebijakan Publik. Jurnal Yuridis. Volume 6 Nomor 1, Juni 2019: 1 -23.

Rumsari Hadi Sumarto. 2017. Etika Publik Bagi Kepemimpinan Pemerintah Daerah. PUBLISIA (Jurnal Ilmu Administrasi Publik). Volume 2, Nomor 2, Oktober 2017.

Ryaas Rasyid. 2007. Makna Pemerintahan: Tinjauan dari Segi Etika dan Kepemimpian. Jakarta: Mutiara Sumber Widya. 
Yeremias T. Keban. 2004. Enam Dimensi Strategis Administrasi Publik - Konsep, Teori, dan Isu. Yogyakarta : Gava Media.

Zainal Abidin Ahmad. 1970. Memperkembang dan Mempertahankan Pendidikan Islam di Indonesia. Jakarta: PT Bulan Bintang. 